\section{B A Institute of \\ YK Business Administration \\ 六下 \\ Karachi \\ Leadership and Ideas for Tomorrow}

Business Review

Volume 11 Issue 1 January-June 2016

$1-1-2016$

\title{
Organizational transformation: Creating the enabling environment through temporary disconnect
}

Syed Irfan Nabi

Institute of Business Administration, Karachi, Pakistan

Follow this and additional works at: https://ir.iba.edu.pk/businessreview

(c) (i)

This work is licensed under a Creative Commons Attribution 4.0 International License.

\section{Recommended Citation}

Nabi, S. I. (2016). Organizational transformation: Creating the enabling environment through temporary disconnect. Business Review, 11(1), 48-61. Retrieved from https://doi.org/10.54784/1990-6587.1077

This article is brought to you by iRepository for open access under the Creative Commons Attribution 4.0 License and is available at https://ir.iba.edu.pk/businessreview/vol11/iss1/5. For more information, please contact irepository@iba.edu.pk. 


\title{
ARTICLE
}

\section{Organizational Transformation: Creating the Enabling Environment through Temporary Disconnect}

\author{
Syed Irfan Nabi \\ Institute of Business Administration, Karachi, Pakistan
}

Abstract

\begin{abstract}
Organizations need to transform to respond to the changes in their operating environment. Despite the awareness that change is the essence of life, humans find it rather elusive to manage it effectively. Most changes are not events but processes, and involve three-stages - Undo, Usher and Consolidate or U2C. Undo the existing order, usher in the new one and, finally, consolidate it. Proper management is required in all three stages. Our understanding of his nature leads us to conclude that a successful change demands a complex handling of environment. Temporary disconnect from the existing order will help in all three stages. It will not only aid in repealing the existing order but will also make the people pliable and ready to accept change. Simultaneously, within the system the new order is introduced together with a control group of role models, to help consolidate the change. Staying connected with external reinforcing influences during the process is bound to tamper change and cause disappointments.
\end{abstract}

\section{Introduction}

"He who rejects change is the architect of decay. The only human institution which rejects progress is the cemetery". Change is the essence of life. There is talk of change all around. We are constantly exposed to it and witness it in our surroundings. Moving from one place to another the landscape changescontinuously presenting us with myriad scenes - lush green fields to dry, barren lands, forests to deserts, mountains to oceans and rivers - some passable others not, but all amazing, wonderful and majestic. We witness changes within ourselves, as well. The physical change in our appearance over the years is such that even our best and closest friends and family members would find it very difficult to recognize us in our photographs taken when we were infants. Change has many dimensions and one of the important ones is related to progress. When we talk of progress we are basicallytalking of change. Human societies are constantly in a flux undergoing change and transforming themselves as superior knowledge, better technology and greater sophistication enters our lives and comes within our reach and grasp. From our pre-historic, stone age days dwelling in caves to the present times we have made tremendous progress. That surely implies colossal change. As they say, the only constant in our lives on earth is change. We live with change. Given this fact, we should have been by now most adept at handling and managing change or transformation of any type. Yet, in reality, it is not so. We find ourselves in a quandary when it comes to managing transformations successfully and effectively. It is not due to any lack of interest in the subject. In fact, much effort has been spent to come to grips with it especially since the 1970 s and many theories and concepts have been introduced. All of them apparently very convincing, thought provoking and effective to a great extent, but doubt still lingers regarding their complete efficacy. Total satisfaction eludes us anduncertainty pervades for none has proven to be outright or unqualified success.

Note: This is an extended version of the research paper "Temporary Disconnect: Creating the Right Environment for Managing Transformation", presented at ELLTA 2012, Langkawi, Malaysia, where only its abstract was published in the conference program/proceedings. 
Why is it so? Basically, it is not the concepts and theories that are so much to blame. The shortcoming lies in flawed management of the environment for these concepts and theories to properly take effect. To be sure environment is considered an important ingredient for change and is given due recognition as a positive source of cultural capital for modifying behavior. But a lack of it, as shown by B in Fig 1, has also to be considered. This, unfortunately, has not been the case; a break from environment, comprising nothing but a void - isolation, if you will - could also be of advantagei.e. something positive. When considering an environment for change both aspects have to be taken into account. This is illustrated in Fig: 1 as environments A and B. Environment A is useful in reinforcing the existing behavior. However, the environment $\mathrm{B}$ is for enabling change. A disconnect from the external environment $\mathrm{A}$ is required to act as a buffer so that it does not adversely affect, interfere or influence the desired change.

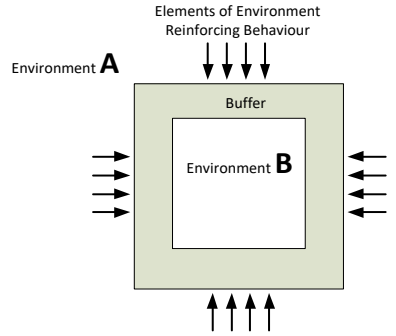

\section{Fig-1: The Two Perspective of Environment}

This environment $\mathrm{B}$ is characterized by absence of influencing factors present in A. It is created by disconnecting from A. This is a transient phenomenon. It is maintained only for so long as is deemed essential. Hence the concept of temporary disconnect, which we consider absolutely necessary for effectively implementing a successful and planed change or transformation.

The idea is to create an enabling environment for change without this environment itself actually getting involved or influencing the process. The importance and role of this change enabling environment may be understood through an example from the physical world: many chemical reactions take place spontaneously in normal room conditions but many others require presence of a special environment to react. These usually relate to specific temperatures and/or pressures. Yet some others may even require a suitable catalyst for a reaction to occur. Thus, these environmental features do not participate per sebut still they are essential, as no reaction will take place in their absence.

Changing a human society is not an event but a process and three stages are involved. First stage is to undo the old order, second is to usher in and introduce the new one, and, third, is to consolidate it: Undo, Usher and Consolidate or U2C.However, to be effective the process of transformation also requires a right change enabling environment as a catalyst throughout the process as shown in Fig -1. In our opinion repealing the existing order and making the people pliable and ready to accept the desired change essentially requires a temporary disconnect from the existing reinforcing environment. For consolidation of the change, continued disconnect has to be maintained to ward off extraneous distractions. Simultaneously, all supportive instruments to fix the change in place have to be applied. This has to be done within the change enabling environment before exposing people back to the environment they came from.

In this paper we would delve into the concept of temporary disconnect and show how powerful a tool it is. No transformation process can be meaningful and long lasting without it. Lack of disconnect has been instrumental in failure of many endeavours to bring 
about a successful change. We would also amplify the conceptual framework of U2C that we consider would be effective in this regard.

The paper begins with arguing the importance of human focus in any change. It is followed by a discussion on nature of humans. Next, managing humans for change is elaborated upon. Resistance and obstacles to change are discussed in the subsequent section followed by the section on the process of change. Finally, the paper concludes with a discussion including future research direction.

\section{Man - The Central Figure}

When we talk about change it is generally understood to imply change in policy or strategy. However, it must be borne in mind that man is the central figure in any change or transformation even if it is clearly a policy change. Starting from the authors of the policy to the owners, managers and leaders responsible forimplementing it, government officials and regulators responsible for oversight, to workers, labourers, suppliers, clients and competitors are all humans. Man is, therefore, the cardinal entity for any change and his instincts and gut feelings have to be taken into account:

Society is founded not on the ideals but on the nature of man, and the constitution of man rewrites the constitutions of states. Events take place through him as well as around him; his ideas and decisions enter vitally into the course of history (Durant \& Durant, 1968a)... only the imagination and initiative of leaders, and the hardy industry of followers, can transform the possibilities into fact; and only a similar combination can make a culture take form over a thousand natural obstacles. Man, not the earth, makes civilization (Durant \& Durant, 1968b).

In recent times, greater realization that man is the central figure has been recognized and many strategies have been devised keeping this fact in mind. Solutions to problems have taken a 'cultural turn' directing attention towards 'soft', cultural and humanistic aspects of organization for business success (Hughes \& Reed, 1992 as cited in Collins, 1996). The shift in emphasis from old transactional leadership and behavioural compliance to the new transformational leadership and the release of organizational talent bears witness to this recognition. Transactional leadership is a process in which the relationship, leader-follower, is reduced to a simple exchange of a certain quantity of work for an adequate price. Contrary to this, transformational leadership is a far more complex process, and includes the 'inner', qualitative, or mental aspects (Simić, 1998). It talks of visionary and inspiring qualities in leaders demonstrating high moral and ethical behaviour. An ability to motivate his followers individually, appreciate and evaluate their attitudes, opinions and contributions; and anability to influence, teach, direct and correct people are all considered essential (Simić, 1998). These are very challenging and difficult qualities to be found or developed in a human. Now things as teams, empowerment, leadership and cultural management are stressed (Elger\& Smith, 1994cited in Collins, 1996). It has also been realized that the skills and attitudes of workers count for more than the technological elegance of an information system when discussing technological change and innovation (Hopper, 1990 cited in Collins, 1996). Thus it can be seen that this realization along with emphasis on softer aspects of leadership, have modified even the language of management.

\section{Nature of Man}

It has been noted with much concern that the results in bringing about change have not been very encouraging. Current literature on transformational change efforts in organizations point to a high rate of failures (Henderson, 2002; Beer \& Nitin Nohria, 2000). To understand the problem, we need to look at man in more detail. Human nature is not easy to get to grips with. Nonetheless, it is pertinent to recognize the complexities even if we have 
not been able to resolve these issues. It is a complex combination of instincts, habits and feelings. 'Each instinct generates habits and is accompanied by feelings. Their totality is human nature' (Durant \& Durant, 1968a). It is compounded by two strange characteristics: the duality of human nature, and the extraordinary capability of the mind. Some four hundred years ago, Descartes (2010) realized that human nature consisted of a duality. This duality comprises of soul and body which are poles apart. We could call it an 'angel-animal' duality because of the two opposing natures that the two command. One as sublime as an angel the other as lowly as an animal. Every person's desires, demands and expectations will vary depending upon his position on this 'angel-animal' scale, which is difficult to gauge. The uncertainty is accentuated because man has the ability to switch from one end to other along the scale - from being very good to being very bad - literally in a twinkling of an eye.

Another familiar feature of humans is the senses. Mother Nature has endowed us with five senses but oddly enough, they are asymmetric. They are biased towards the needs of the body while the needs of the soul are ignored unless an individual makes a conscious effort. However, the problem is we least understand soul, let alone its needs. It is abstract in nature and pertains to the realm of the mysterious and unseen, hence unknowable in the classical sense of science. The body, in contrast, is concrete, visible and the main focus of life on earth. Foremost concern of life is its safety andpreservation. When it comes to the use of senses, therefore, it is sensible to give preference to body over the soul which has no such safety concerns: It may be argued that the body experiences death but the soul does not. The situation may be compared to passengers travelling in an aeroplane. Like the soul, passengers are more important. It is for their convenience that the airlines arrange aeroplanes in the first place. But once seated inside the aeroplane the roles reverse. The enthralled passengers are reduced to secondary status. Safety of the aeroplane takes precedence, and remains so for the entire duration of the journey. In the ultimate analysis our soul may be more important but on earth body takes precedence. Thus, there is a sound logic for this unusual asymmetry in human nature.

Another peculiarity of human nature is its strange tendency to behave in a manner that reminds one of a gyroscope. A gyroscope is basically a spinning body that has two properties. First, it has rigidity in that it is reluctant to change its position in space. Second, it has precession in that when a force is applied to it the resultant movement is displaced by ninety degrees. Humans, too, display rigidity and show great reluctance to change. They also display precession but with a difference that when force is applied their resultant movement, unlike a gyro, is undetermined. Such an inexplicable behaviourresults from humans having an intelligent mind as diverse as people are themselves. 'Peter Senge argues that organizations are nonlinear dynamic systems in which there are many unintended consequences when direct linear action is taken' (Beer \& Nohria, 2000). Sengehas quoted Forrester (1971) who calls this phenomenon: "the counter-intuitive nature of complex systems," arguing that human intuition consistently leads people to want to do virtually the opposite of what would really accomplish their aims' (Senge, 2000).

In recent times much progress has been made in artificial intelligence (AI) and a great number of machines and gadgets of everyday use are now incorporating computers with a built-in AI feature. Any body who has used such gadgets knows what a difference AI makes (and pain it causes when it misbehaves). But this AI is limited to the level of sophistication attained in technology and thegenius of its software programmers. When dealing with humans the factor of his intelligence (real intelligence at that, and uncannily varied) is generally overlooked. They are considered no better than homogeneous 'zombies' when devising programmes for them. Talking about early factory owners justifying their exploitation of poor labourers, Macpherson (cited in Gerhardt, 2010), 'pointed out that wage labourers were already of a very low status'.

Gerhard (2010) goes on to say that: 
To the employers, they were just 'hands', not respectable artisans or family men. They felt comfortable about hiring these least powerful members of the society at below subsistence price - an attitude similar to the later colonialists, or even to the current chief executives who have few qualms about using cutprice labour in the Philippines or Bombay to make their products cheaply. After all, they should be glad to have work - at any wage - goes the familiar argument then and now. All share an assumption that those who are least powerful are also less human. ... Their humanity becomes relatively invisible and abstract. In early industrial capitalism, there was a sense that an employee was already a degraded person, so most employers did not concern themselves with his loss of personal initiative and autonomy.

A common example in our daily lives may be seen if we note our behaviour with 'low status' just 'hands' around, i.e. in the presence of servants, waiters and chauffeurs. We are inclined to ignore their 'intelligent' presence and consider them as robots with no mind of their own. We tend to have no qualms discussing even confidential matters in their presence. Probably we think they are deaf, too!

Thus we can see that attitudes have not changed much. Therefore, when dealing with human-centric systems we still face problems of uncertainty and failures.

\section{Managing Man for Change}

Henderson (2002) has categorized theories regarding bringing about change in man under two heads:

Transformative Learning, which focuses on how individuals change their perspectives, primarily through the process of critical reflection, and

Transformational Change, which has organizational change as its primary focus. [It] finds its origins in the social sciences, which examine the effect of social influences that are external to people.

These two relate to the internal and external aspects, respectively. It is similar to nature and nurture issue. For change, learning is a prerequisite. Learning is a complicated affair and includes both internal and external aspects. The external inputs are received in the mind through our senses. These are processed in the mind to result in a response which could either be spontaneous without much thought, or deliberate based on critical reflection. The critically reflected responses affect the inner personality, the soul, and result in the desired change. On the other hand, mind has the capacity to filter inputs. Based on its intelligence it can block out any information that it does not want to register. Thus, debate on transformative learning and transformational change may continue without ever getting a testable truth that satisfies the physical world of science. Therefore, taking cognizance of this fact, there is a need to move on to more applied side of change.

We now know the issues involved in dealing with humans are serious and require careful handling. It shows the extent of the problem we face in transforming human organizations and societies. It also attests to the reasons why so many very good theories, strategies and concepts lie dumped along the route to consistently achieving guaranteed, sure success. No matter how awkward or inconvenient these human traits may seem, they must be faced squarely. Neither denying them nor use of force would stand us in good stead. On the other hand, there would be no use trying to figure out the complex and elusive nature we have discussed above individually for each person. Any attempt to do so would invariably lead us to discussing spirituality, religion and metaphysics. It would only make us all very uncomfortable and land us in a confusing maze of unnecessary detail regarding each individual performance as humans are nothomogeneous. 
Our goal in the paper is to suggest a mechanism to bring about a change in society. It is not to assess individuals. Thus getting unduly stuck in detail at the cost of looking at the bigger picture would not be of much help. Therefore, we would bypass the intricacies, and focus on mechanisms that would help us bring about the desired change in people. The importance of finding this larger general picture is further elaborated in the succeeding paragraphs.

This issue of focusing on larger picture or zooming in to a particular aspect crops up wherever humans are involved, irrespective of the field. A very interesting and sensible advice in this regard comes from the medical field of homeopathy. They divide a patient's symptoms under two heads: general, which applies to the patient as a whole, and particular, which refers to a particular part of the body affected. Emphasizing the importance of the general over the particular, Dr. Kent (2004), states in the preface of his book that, 'it should be understood that a circumstance that makes the whole being feel better or worse is of much greater importance than when the same circumstance only affects the painful part, and these are often quite opposite'.

Tyler and Weir (2002), amplify it further in much greater detail:

And now, at last, you come to the PARTICULARS - the symptoms that bulk so largely for the patient, and for which he is as a matter of fact, actually consulting you. You will have taken them down first ... but you will consider them last. ...because they are not general to the patient as a living whole, but onlyparticulars to some part of him. In a great railway system, for instance, a strike that raises the price of fuel for a few weeks, an accident on the line that means compensation to the injured, and replacement of rolling stock, and repair of a few yards of permanent way, are less vital to the Company than the brain quality of its General Manager, or the force, competence and activity of the Chairman and the Board of Directors. Make the executive of the Company efficient and it will deal in the best way with details. ... Start for the Particulars, and see where they land you! In the body politic, where the executive is not sound, you deal with lax discipline here, with peculation there, with incompetence, and disorder, and slackness, and inefficiency. There is rottenness at the core; and you will find that as fast as you clear up one mess, the system breaks down at a new part. Go for the Management; put that right; and let it act. ... Never juggle with "Particulars" at the expense of the life of the whole.

\section{Impact of Environment}

Research in the field of genetics is revealing that genes involved in social behavior do not turn on or off by themselves but are affected by environmental conditions. Recent epigenetic studies discussed in Moalem \& Prince (2007) and Gerhard (2010) show that factors like the food we eat or the cigarettes we smoke can trigger them into activity. Psychiatrist Michael Rutter (Rutter, 2006 cited in Gerhard 2010) argues that genes play their part in complex reciprocal interactions with the environment. What it means is that although the genes are present in the DNA but they may be turned on or off depending on the environment around the mother. It has been shown that certain compounds can attach themselves to specific genes and suppress their expression. These compounds act like genetic light switch, essentially turning off the genes they attach to. This process of genetic suppression is called DNA methylation. Methylation occurs when a compound called a methyl group binds to a gene and changes the way that gene expresses itself, without actually changing the DNA. (Moalem \& Prince, 2007; Rutter, 2006 cited in Gerhard 2010).

Prominent evolutionary thinkers Eldredge and Gould (1972) advanced the theory of punctuated equilibrium which states that evolution was characterized by a state of general 
equilibrium punctuated by periods of significant change brought about by large environmental shifts. Environment is capable of triggering massive changes in humans (Moalem \& Prince, 2007). These changes wrought by environment are deep seated, affecting the very genetic make up of humans. The research is in its infancy and still ongoing but provides evidence of the power of environment to conveniently and effectively manage change in people. It does that without getting involved in the complex issues of human nature. Therefore, we consider managing the environment is a better way of effectively bringing about a desired change. Probably it is the only way to do so.

\section{Power of Isolation}

By nature, humans are social animals and find themselves very uncomfortable when they are alone. It creates considerable alarm, and can therefore, be used as an effective instrument to exert influence. Throughout history it has been used for many purposes and is still in vogue, testifying to its efficacy. In popular view it has a very negative connotation, implying punishment. Mere mention of it is enough to cause concern. Putting criminals behind bars in a prison, or, worse, solitary confinement, imposing sanctions on countries, layingsiege to a city during war or blockading its seaports, and no fly zones can all be categorized under this head. Declaring someone as an outcast, or banishing him from the country is to the same effect. Isolation is also used on many other occasions and for a variety of purposes. Blocking roads and holding people back during VIP movements, designating red zones and restricted areas in cities where normal entry is barred, use of high walls, razor and barbed wires, placing of obstacles around important buildings and sites, and use of guards, sentries and escorts are all examples of isolation. Its use as a protective measure is also evident in such activities. Use of identification papers, permits, passports and other such documents and devices help in proving bonafides. It leads to creating privileged classes and for discriminating amongst people. Following an act of crime, the area is put in lockdown mode and the scene is cordoned off. Normal access is denied as the concerned authorities go about collecting evidence and trying to nab the criminals. Thus its use in fighting crime and conducting investigations is well established.

In sickness we end up with a running fever which not only makes us dull and lethargic but also causes our body to ache and pain. Feverishness then forces the patient to withdraw from all activities, isolating himself and taking time off to rest. This gives the body a chance to set the healing process in motion. Disconnecting patients from the healthy humans has been regularly applied in medical care successfully in the shape of isolation wards, quarantines and intensive care units. Therefore, we can say that isolation is a wellestablished natural phenomenon to help change.

In March 1997, thirty-nine members of a communal religious group, called Heaven's Gate, carried out a mass suicide at the approach of comet Hale-Bopp. Almost two decades earlier another mass suicide at Jim Jones's 'Peoples Temple' at Jonestown, Guyana, claimed over nine hundred lives. These are shocking stories about horrible activities that take place within the cults. But they speak volumes about the power and effectiveness of disconnect, and its ability to change normal human behaviour to such an extent that they are willing to even sacrifice their lives. The single most glaring characteristic of fringe groups and extremist organizations who create cults is that they live in communities isolated from society.

Probably suicide bombers are also processed in a similar manner. Their precursors, the Japanese Kamikaze suicide pilots of World War II, were a whole lot more sophisticated. Their segregation was full of great symbolism:

From the beginning Admiral Onishi had the presence of mind to create decorative and symbolic trappings for the sacrificial fliers.... They were, he had told the first unit, already gods, and should have no further interest 
in human affairs.... On completion of their missions, their spirits would fly to the Yasukani shrine near the Imperial Palace in Tokyo, and there would be enshrined forever; all Japan would come to pay them homage.... The admiral handed over special bottles of water, from which the Kamikaze pilots were to take a final drink.... 'hachimaki' became another symbol of the suicide corps.... In the days of the samurai a warrior who tied a white towel around his head signified that he was preparing to fight to the death.... (it was) decorated with poetic calligraphy, most of it mystical in nature.... The admiral promised them that he personally would make sure that their brave deeds were made known to the Emperor (Hoyt, 1983).

Even Military establishments believe in segregated enclaves and depend much on symbolism. Cloistered in their cantonments it is amazing to see how quickly a bunch of young, disorderly civilian kids transform into fighting soldiers at their academies. Secluded and living in a world of their own, these civilians first turn into soldiers and then their loyalty and discipline is consolidated to an extent that they are able to face all odds, even to the peril of their lives. Their uniforms, intricate range of ceremonial dresses, ribbons, medals, emblems and insignias, rank structures and badges, coat of arms, elaborate ceremonial drills, parades and marches in step with the beat of the drums, military bands in attendance and much fanfare, fluttering flags and ensigns are, indeed a treat to watch. They must surely stiffen a few spines amongst the participants even if they are not aware that these are meant to create and sustain changed human behavior.

The British were heavily out numbered in the Subcontinent during their colonial rule. Allen (2001) mentions the use of pompous title 'The Honorable Company' orits local interpretation 'Kampani Bahadur' that the East India Company liked itself to be referred by, and employing the pretentious term 'LatSaheb' ('Lord and Master') for its leader. Young British officers newly arriving in the Subcontinent were groomed o become rulers. After landing in India, they were kept secluded at Bombay for a while to unlearn the norms of social life they were used to back home in Britain. They were taught to live without unduly mixing with the natives. This was done to establish an aura of outright superiority, invincibility and infallibility over the natives. Thus they could rule effectively.

If you look at the examples enumerated above a striking feature of isolation common to all is that they have a very negative and an unsavory connotation about them. They are considered an extreme and a revolutionary step. Any thought of isolating ourselves voluntarily under normal circumstances is simply rejected out of hand. It creates fear in our minds. We are spending huge amounts of resources and energy in painstaking efforts to detect if life of any sort exists anywhere in the vastness of space. The thought that we are all alone in this universe causes us discomfort. However, it must be realized that changes to human behaviour, whether normal or otherwise, are all revolutionary in nature and demand very serious considerations right from the outset. The question arises that if so much is known regarding the efficacy and influence of isolation in changing behaviour, why is it not considered for inclusion in the strategies on offer? In our opinion, this is a major flaw in these strategies.

\section{Role of Role-Model}

A path breaking research regarding important human characteristics was conducted by Lawrence and Nohria (2002) of Harvard Business School. They concluded that the way we act is the result of a deliberate internal battle constantly raging among our four innate, subconscious brain-based drives. They claim these drives are to acquire, to bond, to learn and to defend. In a state of isolation, cut off from friends and families, there is not much to acquire, bond or defend. The only drive that remains in the circumstance is to learn. 
An interesting incident involving a group of fifteen monkeys occurred at the world's leading primate research centre at Kyoto, Japan. These monkeys were kept in their forest home secluded by a five meter high electric fence. They flung themselves over the fence to escape using the branches of trees as catapult by bending and releasing them. Having escaped, they did not know what to do next. They hung around and were lured back in with peanuts (Demetriou, 2010). Despite their isolated environment the monkeys demonstrated that their drive to learn had not diminished. If anything it had enhanced. However, their other drives seem to have suffered a decrease. Thus we believe that although the incident occurred with primates, the effect of isolation on human drives would not be different.

In a Halloween study, researchers instructed visiting trick-or-treaters to take only one item from a candy bowl placed inside a house. Eighty three percent took extra candy when the first kid in the group did likewise. This percentage reduced to only eight when the kids arrived alone with nobody to set a bad example (Diener, Fraser, Beaman, et al., 1976 as cited in Sommers, 2011). There is a marked difference in our behaviour when alone as compared to when we are in company. Similarly, a very interesting 'line judging' study was first conducted by a Swarthmore College psychologist Solomon Asch (1955). He presented a diagram of three lines of differing lengths and asked the subjects to choose one amongst them that matched exactly with a separate solitary line. When asked individually, there was no problem in getting the right answer. However, in the company of others it was a different matter. Asch arranged actors to be 'the others' and coached each of them to unanimously give wrong answers. In their presence, seventy five percent of the participants went along with the wrong answer at least once. The reason is that 'being wrong is easier than breaking rank'(Sommers, 2011).People submit uncritically and painlessly to external manipulation. Any given idea or value can be 'sold' or 'unsold'. It was also discovered that 'the presence of a supporting partner depleted the majority of much of its power (to influence)... reducing it to one-fourth. ...With his support the subject usually resisted pressure from the majority'(Asch, 1955).

Thus, there is also a strong urge toward social conformity influencing our actions. We would rather go against our best judgement than go against the consensus view of the group we are with.

'You can create new norms by modeling the very actions you hope to see in others. Recruit friends to populate a long line outside your restaurant, club or gallery opening'(Sommers, 2011). One of the students of Sommers reported another example of such modeling:

My colleague was getting frustrated because she had sent several e-mails explaining how to fill out the two relatively simple forms, and no one could manage to complete them correctly. We decided to try taping up sample filledin forms and ever since, we haven't had a problem (Sommers, 2011).

Thus, presence of others provides us both mutual support and role models and any given idea can then be 'painlessly sold'.

Conversely, when we like a person to give up his habit, we need to generate an opposite effect. Instead of creating conformity, we are interested in curtailing it so that the change is easily accepted. Ideas entrenched in a person's mind need to be deleted or 'unsold'. 'Reverse engineer these situations in the direction of independence. Anything you can do to emphasize individual identity has the potential to reduce conformity' (Sommers, 2011).

In the line judging study when a supporting partner 'deserted' the subject as coached, Asch (1955) was surprised to:

Find that the experience of having had a partner and of having braved the majority opposition with him had failed to strengthen the individuals' 
independence. As long as the subject had anyone on his side, he was invariably independent, but as soon as he found himself alone, the tendency to conform to the majority rose abruptly.

Therefore, whether the purpose is to introduce a new idea or to delete an old one, a suitable environment needs to be provided. However, the environment in the two situations would be different and quite the opposite of each other. When the purpose is to instill an idea, an environment of support from partners has to be developed and maintained together with providing dedicated role models. Failure to maintain this favorable supportive pressure could weaken the resolve.

Therefore, the favorable support needs to be maintained for as long as it is necessary for it to be ingrained firmly in the very soul of the person's conscience, and his commitment to the cause is consolidated. On the contrary, as we saw in the Halloween study, kids arriving solo were the most likely to follow the given instructions, suppressing their urge to steal candy. Thus, if the purpose is to delete an idea, an environment devoid of support has to be created.

In other words, when discussing change, we are faced with two environments. One exists within the system or organization and needs to be actively controlled in order to bring about a change. There is another environment of concern which exists outside the system. So far our discussion has centered on environment within the system. As for the environment outside, it must stay disconnected to obviate any chance of extraneous forces adversely influencing the desired change outcome.

Transformation can be compared to changing gear while driving a motor vehicle. In order to do so it is necessary to press the clutch, this effectively, though temporarily, disconnects the wheels from the engine. It is just not possible to change gear while the engine remains connected to the wheels. If a computer hangs or misbehaves, the manufacturers provide it with a reset button to return it to its default values. If there is a reset button for humans it has to be this disabling environment cutting him off from any support to reinforce and maintain his posture.

\section{Resistance and Obstacles to Change}

Managing change is a challenging task because of the resistance that can be encountered. To start with, as we have discussed above, there is a natural reluctance to change. There will also be resistance from those who are liable to lose out as a result of change. If a restructuring or downsizing is contemplated, those likely to be made redundant might instigate the remaining staff to oppose the change or approach external agencies having influence. There may be those who are scared of the change due to any number of reasons. It could be due to the fear of the unknown or due to reluctance of putting in extra effort. It could even be due to their perception that the change would bring about a certain amount of hardship with it. Another group resisting change comprises those who have stakes in the status quo. They may be enjoying many benefits from the system, and, as a consequence would probably have gained much power, wealth and influence. They pose a considerable challenge to change especially if it has even the slightest chance of affecting their status. Direct confrontation with the forces of status quo could very easily undo the whole process. Change is generally deemed as encroaching upon freedom, comfort or demanding extra effort, even if it is not really so.

External interference is another obstacle to desired change. It could be in the form of political pressure being exerted on behalf of those likely to lose out due to the change. Unscrupulous elements within the regulator authority could also pose problems either on their own or in collusion with competitors. Globalization is a popular byword these days. Much meddling could be caused in its name. It could pose serious problems. It may be noted that: 
Every Great Group is an island - but an island with a bridge to the mainland.... People who are trying to change the world need to be isolated from it, free from its distractions, but still able to tap its resources (Bennis \& Biederman, 1996).

Therefore, whatever the nature of interference, it is absolutely necessary to keep it at bay to ensure effective change.

\section{The Process of Change}

Change is challenging and usually calls for a radical departure from the past. New ways of thinking, working, and acting have to be learnt and old ways have to be unlearnt.

As long as the deep structure is intact, it generates a strong inertia, first to prevent the system from generating alternatives outside its own boundaries, then to pull any deviations that do occur back into line. According to this logic, the deep structure must first be dismantled, leaving the system temporarily disorganized, in order for any fundamental changes to be accomplished. Next, a subset of the system's old pieces, along with some new pieces, can be put back together into a new configuration, which operates according to a new set of rules (Gersick, 1991).

Keeping all the lessons in mind we consider creating a change is a three stage process: Undo, Usher and Consolidate or U2C. Undo the existing order, usher in the new one and, finally, consolidate it. The steps for bringing about a change are straight forward, but they require a catalyst in the form of the right change enabling environment.

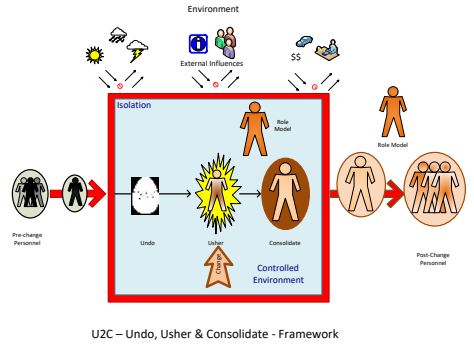

Fig-2: The U2C Framework

First of all the system must be isolated to create a disconnect from all external forces liable to cause interference as shown in Fig -2. This disconnect, though temporary in nature, must be maintained during the change process and for as long as it is deemed necessary. We now have an isolated system that should help in undoing the entrenched order. We know from the study of the Halloween kids that an isolated person, devoid of any support, is most likely to follow any instructions that are given. In our case it will make the system pliable and ready to accept change.

In the next stage, we need to introduce and usher in the new order. All possible and available means at the disposal of the organization must be utilized to clearly disseminate the new instructions amongst the people. We know that in an isolated environment the drive to learn is not only active but also enhanced. Under the circumstances assimilation of new rules, regulations, orders and procedures would be facilitated. Simultaneously, the third stage of consolidation would be initiated in the form of role models, actively participating and practically showing how the changed order is to be implemented. We know from the study of Asch's lines the powerful impact of a partner. These role models would satisfy that need for support and provide the necessary reinforcement for the purposes of consolidation. 
It should be noted that there are many ways of creating isolation. It can be physical, intellectual or emotional. Another point to note is that while a disconnect is maintained with the external world, within the system total mutual trust and support is provided to reinforce and consolidate the change. With the enclosed system all the four human drives would then start to function normally. Together with the drive to learn, the other three drives to acquire, bond and defend would be activated to promote a healthy gelling of change.

\section{Discussion}

Change is the essence of life but it is not easy to get to grips with it because of human nature. In order to effect a change, we need to understand the critical role of environment. A temporary disconnect is considered necessary to create the right environment for managing change or transformation. Change is a three stage process consisting of undoing the old order, ushering in the new one and then consolidating it. However, certain pitfalls exist and must be catered for. Strategies on offer for change do take human factor into consideration but the emphasis is on academics, consultants and practitioners. Workers and labourers are given scant regard. This asymmetry needs to be addressed. Another issue pertains to judging success of a change. It appears that greater importance is placed on shareholder value than on the sustained strength of the enterprise. Under the circumstances it would be difficult to motivate the workers to give their full commitment knowing that the benefit will accrue to the outsider shareholder and not so much to the company workers. True, the management with stock options also stands to gain but the workers would generally be outside the loop for they are not much into stock market because of their pecuniary disadvantage. It will cause disconnect within the system between the labour and the leader. With stock price in mind the leaders would stay connected to the outside and disconnect within. Just the opposite of what we consider essential for success. This paper discusses how to bring about a successful change. It was taken for granted that change being initiated is good for the company. However, this is not always the case. Many changes are made where they are really not needed. Durant cautions in The Lessons of History:

Out of every hundred new ideas ninety-nine or more will probably be inferior to the traditional responses which they propose to replace. No one man, however brilliant or well-informed, can come in one lifetime to such fullness of understanding as to safely judge and dismiss the customs or institutions of his society, for these are the wisdom of generations after centuries of experiment in the laboratory of history. So the conservative who resists change is as valuable as the radical who proposes it - perhaps as much more valuable as roots are more vital than grafts. It is good that new ideas should be heard, for the sake of the few that can be used; but it is also good that new ideas should be compelled to go through the mill of objection, opposition, and contumely; this is the trial heat which innovations must survive before being allowed to enter the human race (Durant \& Durant, 1968a).

What it means is that there is a need to research more about what changes are really needed before rushing into the venture.

\section{Acknowledgement}

This research was scholarly supported by Syed Niaz Nabi. The author wishes to acknowledge that the fundamental idea and subsequent refining of it was provided by Syed Niaz Nabi. For which the author is greatly indebted to him.

\section{Note}

1- By James Harold Wilson, (11 March1916 - 24 May1995), Prime Minister of the United Kingdom from 1964 to 1970 , and again from 1974 to 1976. Speech to the 
Consultative Assembly of the Council of Europe, Strasbourg, France (January 23, 1967); reported in The New York Times (January 24, 1967), 12

\section{References}

Allen C (2001) Soldier Sahibs: The Men Who Made the North-West Frontier. Little, Brown Book Group Limited.

Asch SE (1955) Opinions and social pressure. Scientific American, 193(5), 31-35.

Beer M and NohriaNitin (eds) (2000) Breaking The Code of Change. Harvard Business School Press.

Bennis WG and Biederman PW (1996) Organizing Genius. Reading, Massachusetts, USA, Addison-Wesley.

Collins D (1996) New paradigms for change? Theories of organization and the organization of theories. Journal of Organizational Change Management, 9(4), 9-23.

Demetriou D (2010) Monkeys use trees to catapault themselves out of Japanese laboratory. Telegraph.co.uk, 7th July.

Descartes R (2010) Passions of the Soul.

Diener E, Fraser S, Beaman A, et al. (1976) Effects of deindividuation variables on stealing among Halloween trick-or-treaters. Journal of Personality and Social Psychology, 33(2), 178-183.

Durant W and Durant A (1968a) Character and History. In: The lessons of history, The story of civilization, Simon and Schuster.

Durant W and Durant A (1968b) History and The Earth. In: The lessons of history, The story of civilization, Simon and Schuster.

Eldredge N and Gould SJ (1972) Punctuated equilibria: an alternative to phyletic gradualism. Reprinted in N. Eldredge Time frames. Princeton: Princeton Univ. Press, 1985,193-223. In: Schopf TJM (ed.), Models in Paleobiology, San Francisco, USA, Freeman, Cooper \& Co., 82-115.

Elger T and Smith C (eds) (1994) Global Japanization: the transnational transformation of the labour process /. London;, Routledge,.

Forrester JW (1971) The counterintuitive behavior of social systems. Technology Review, 73(3), 52-68.

Gerhardt S (2010) The Selfish Society: How We All Forgot to Love One Another and Made Money Instead. UK, Simon \& Schuster, Limited.

Gersick CJG (1991) Revolutionary change theories: A multilevel exploration of the punctuated equilibrium paradigm. Academy of management review, 16(1), 10-36.

Henderson GM (2002) Transformative Learning as a Condition for Transformational Change in Organizations. Human Resource Development Review, 1(2), 186-214.

Hopper MD (1990) Rattling SABRE- new ways to compete on information. Harvard Bus. Rev., 68(4), 118-125.

Hoyt EP (1983) The kamikazes. Ferozsons (Pvt) Ltd., Lahore, 1986. London, Robert Hale Ltd.

Hughes M and Reed M (1992) Rethinking Organization: New Directions in Organization Theory and Analysis. SAGE Publications. 
Kent JT (2004) Repertory of the Homoeopathic MateriaMedica. B. Jain Publishers.

Lawrence PR and Nohria N. (2002) Driven: How Human Nature Shapes Our Choices. Warren Bennis Signature Books, San Francisco, CA, USA, Jossey-Bass, Wiley.

Macpherson CB (1962) The political theory of possessive individualism: Hobbes to Locke. Oxford University Press.

Moalem S and Prince J (2007) Survival of the Sickest: A Medical Maverick Discovers Why We Need Disease. HarperCollins.

Rutter M (2006) Genes and Behavior: Nature-Nurture Interplay Explained. John Wiley \& Sons.

Senge PM (2000) The Puzzles and Paradoxes of How Living Companies Create Wealth: Why Single-Valued Objective Functions Are Not Quite Enough. In: Beer M and NohriaNitin (eds), Breaking the Code of Change, Harvard Business School Press, p. 64.

Simić I (1998) Transformational Leadership - The Key to Successful Management of Transformational Organizational Changes. Facta Universitatis, Economics and Organization, 1(6), 49-55.

Sommers S (2011) Situations Matter: Understanding How Context Transforms Your World. New York, NY, USA, Riverhead Books, Penguin Group US.

Tyler ML and Weir J (2002) Repertorising. B. Jain Publisher Pvt Ltd, Reprint- 2002. 